\title{
Infection Control
}

\section{Hospital Epidemiology}

Volume 36, No 4

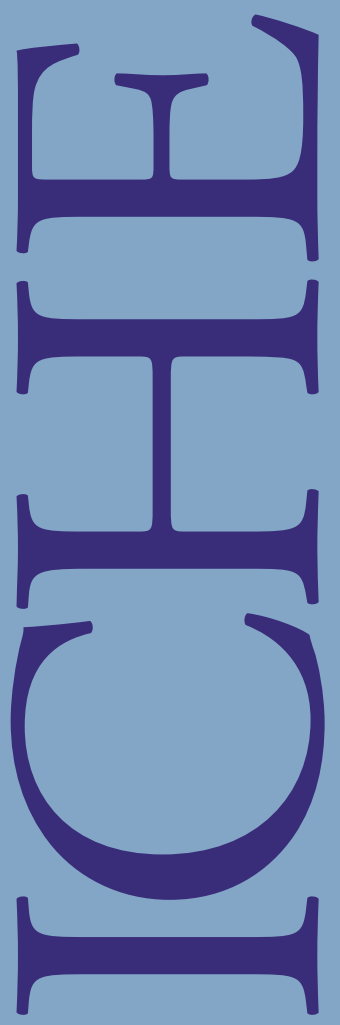

IGNAZ SEMMELWEISS 

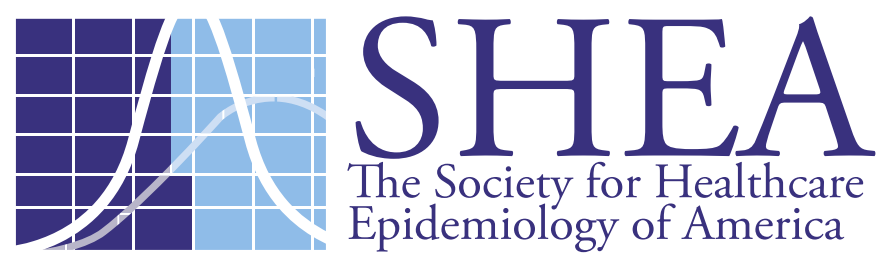

The Society for Healthcare Epidemiology of America

\section{Spring 2015 Conference SCIENCE GUIDING PREVENTION}

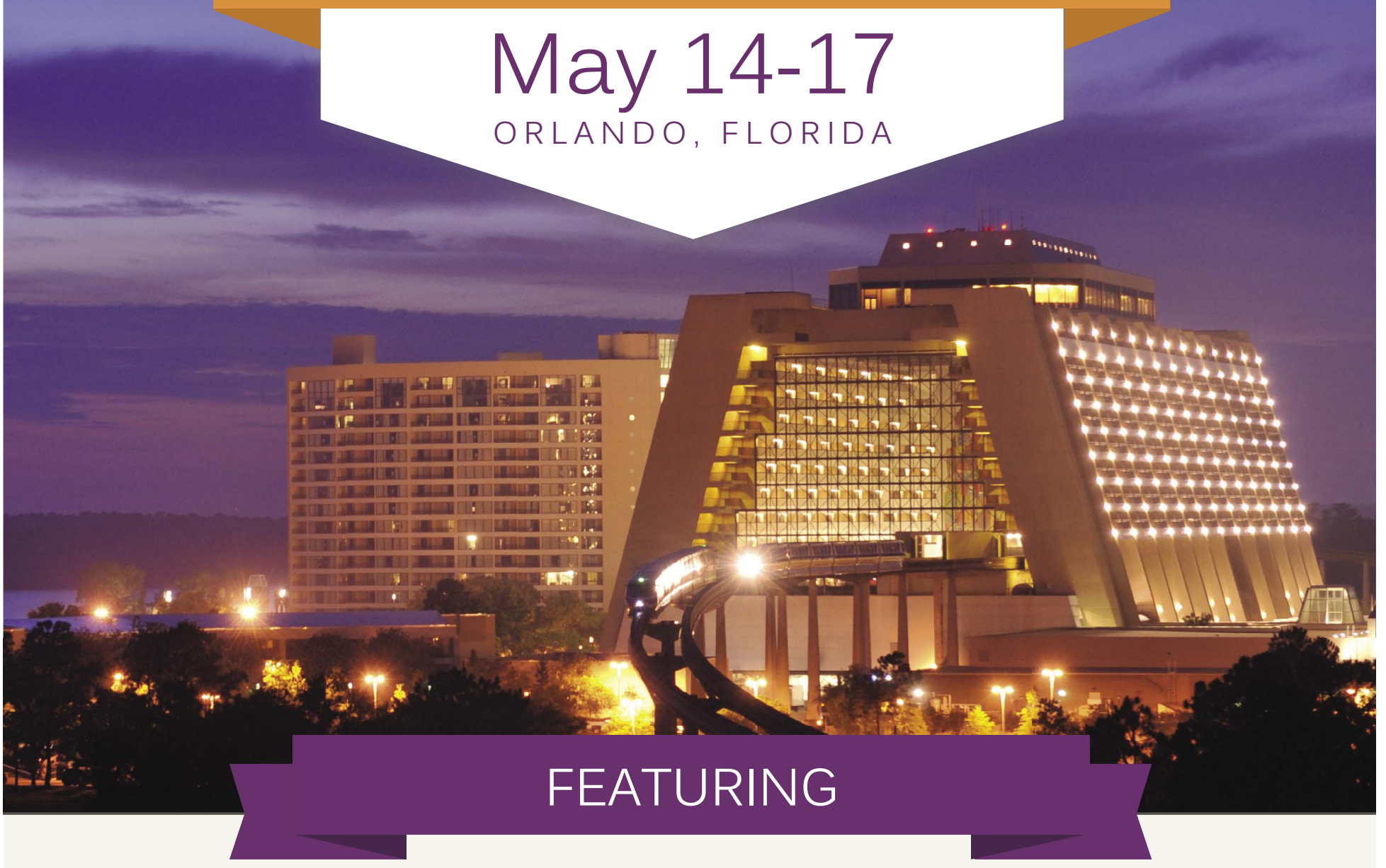

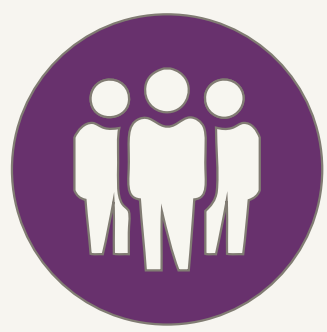

Expanded Networking \& Mentoring Opportunities

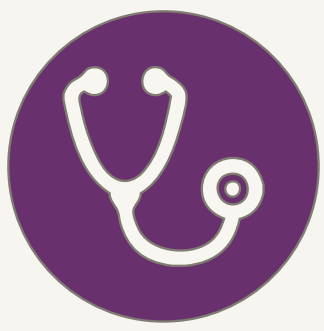

Focused Workshops on

Pediatrics \& Antimicrobial Stewardship

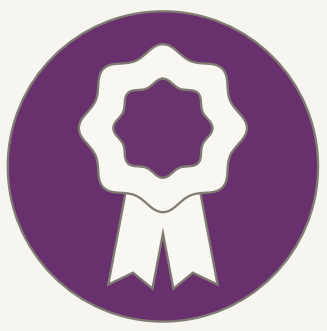

Two SHEA Certificate

Course Tracks 


\section{CONTENTS}

\section{SHEA White Paper}

369 Guidance for Infection Prevention and Healthcare Epidemiology Programs: Healthcare Epidemiologist Skills and Competencies

Keith S. Kaye, Deverick J. Anderson, Evelyn Cook, Susan S. Huang, Jane D. Siegel, Jerry M. Zuckerman and

Thomas R. Talbot

\section{Original Articles}

381 Regional Infection Control Assessment of Antibiotic Resistance Knowledge and Practice

Stephanie R. Black, Kingsley N. Weaver, Robert A. Weinstein, Mary K. Hayden, Michael Y. Lin,

Mary Alice Lavin and Susan I. Gerber

387 Risk Factors for gyrA and parC Mutations in Pseudomonas aeruginosa

Valerie C. Cluzet, Ebbing Lautenbach, Irving Nachamkin, Mark S. Cary, Neil O. Fishman, Natalie N. C. Shih, Knashawn H. Morales and Darren R. Linkin

394 Extensive Dissemination of Extended Spectrum $\beta$-Lactamase-Producing Enterobacteriaceae in a Dutch Nursing Home Ina Willemsen, Jolande Nelson, Yvonne Hendriks, Ans Mulders, Sandrien Verhoeff, Paul Mulder, Robert Roosendaal, Kim van der Zwaluw, Carlo Verhulst, Marjolein Kluytmans-van den Bergh and Jan Kluytmans

401 Universal Screening and Decolonization for Control of MRSA in Nursing Homes: A Cluster Randomized Controlled Study

Cristina Bellini, Christiane Petignat, Eric Masserey, Christophe Büla, Bernard Burnand, Valentin Rousson, Dominique S. Blanc and Giorgio Zanetti

409 Diminishing Surgical Site Infections in Australia: Time Trends in Infection Rates, Pathogens and Antimicrobial Resistance Using a Comprehensive Victorian Surveillance Program, 2002-2013

Leon J. Worth, Ann L. Bull, Tim Spelman, Judith Brett and Michael J. Richards

417 Surgical Site Infection after Renal Transplantation

Anthony D. Harris, Brandon Fleming, Jonathan S. Bromberg, Peter Rock, Grace Nkonge, Michele Emerick, Michelle Harris-Williams and Kerri A. Thom

424 Central Line-Associated Bloodstream Infections in Non-ICU Inpatient Wards: A 2-Year Analysis Yoona Rhee, Michael Heung, Benrong Chen and Carol E. Chenoweth

431 Impact of Universal Gowning and Gloving on Health Care Worker Clothing Contamination Calvin Williams, Patty McGraw, Elyse E. Schneck, Anna LaFae, Jesse T. Jacob, Daniela Moreno, Katherine Reyes, G. Fernando Cubillos, Daniel H. Kett, Ronald Estrella, Daniel J. Morgan, Anthony D. Harris and Marci Drees

438 Cost-Effectiveness Analysis of Fecal Microbiota Transplantation for Recurrent Clostridium difficile Infection Raghu U. Varier, Eman Biltaji, Kenneth J. Smith, Mark S. Roberts, M. Kyle Jensen, Joanne LaFleur and Richard E. Nelson

445 Molecular Epidemiology of Clostridium difficile Infections in Children: A Retrospective Cohort Study Larry K. Kociolek, Sameer J. Patel, Stanford T. Shulman and Dale N. Gerding

452 Risk Factors for Recurrent Clostridium difficile Infection: A Systematic Review and Meta-Analysis Abhishek Deshpande, Vinay Pasupuleti, Priyaleela Thota, Chaitanya Pant, David D.K. Rolston, Adrian V. Hernandez, Curtis J. Donskey and Thomas G. Fraser 


\section{Concise Communications}

461 Examining Hospital Patients' Knowledge and Attitudes Toward Hospital-Acquired Infections and Their Participation in Infection Control

Holly Seale, Yuliya Novytska, Julie Gallard and Rajneesh Kaur

464 Substantial Variation in Hospital Rankings after Adjusting for Hospital-Level Predictors of Publicly-Reported Hospital-Associated Clostridium difficile Infection Rates

Rupak Datta, N. Neely Kazerouni, Jon Rosenberg, Vinh Q. Nguyen, Michael Phelan, John Billimek,

Chenghua Cao, Patricia McLendon, Kate Cummings and Susan S. Huang

467 The Potential Impact of Excluding Funguria from the Surveillance Definition of Catheter-Associated Urinary Tract Infection

Kristen V. Dicks, Arthur W. Baker, Michael J. Durkin, Sarah S. Lewis, Rebekah W. Moehring,

Deverick J. Anderson, Daniel J. Sexton and Luke F. Chen

470 Overtreatment of Asymptomatic Bacteriuria: Identifying Targets for Improvement

Sarah Hartley, Staci Valley, Latoya Kuhn, Laraine L. Washer, Tejal Gandhi, Jennifer Meddings,

Carol Chenoweth, Anurag N. Malani, Sanjay Saint, Arjun Srinivasan and Scott A. Flanders

474 Antibiotic Prescribing at the Transition from Hospitalization to Discharge: A Target for Antibiotic Stewardship Norihiro Yogo, Michelle K. Haas, Bryan C. Knepper, William J. Burman, Philip S. Mehler and Timothy C. Jenkins

479 Risk Factors for Central-Line-Associated Bloodstream Infections: A Focus on Comorbid Conditions Christopher S. Pepin, Kerri A. Thom, John D. Sorkin, Surbhi Leekha, Max Masnick, Michael Anne Preas, Lisa Pineles and Anthony D. Harris

\section{Research Brief}

482 Compliance with the World Health Organization Hand Hygiene Technique: A Prospective Observational Study Sarah Tschudin-Sutter, Daniel Sepulcri, Marc Dangel, Heinz Schuhmacher and Andreas F. Widmer

\section{Letters to the Editor}

484 Sterilization Indicators in Central Sterile Supply Department: Quality Assurance and Cost Implications Debabrata Basu, Sanjay Bhattacharya, Aseem Mahajan, Venkata Raman Ramanan and Mammen Chandy

486 Making the Case for Textiles with a Dual Mechanism of Action Amber H. Mitchell

487 Mobile Phone Microbial Contamination Among Neonatal Unit Healthcare Workers Giovanni Battista Orsi, Fabio Natale, Gabriella d'Ettorre, Carmela Protano, Vincenzo Vullo and Mario De Curtis

489 Inconsistencies Regarding the Number of Outbreaks and Mortality Rate of Hospital-Acquired Infections Caused by Contaminated Propofol Andrés Zorrilla-Vaca and Paola A. Vaca-Gonzalez

490 Potential Risk of Aerosol-Borne Francisella tularensis Transmission in the Operating Room Sören L. Becker, Wolf D. Splettstoesser, Yoo-Jin Kim, Thomas Junghanss, Mathias Herrmann, Gregor Wolf and Maximilian Linxweiler

492 Port-Related Nontyphoidal Salmonella Bacteremia Hung-Jen Tang, Chien-Ming Chao and Chih-Cheng Lai 
An Official Publication of the Society for Healthcare Epidemiology of America

\section{EDITOR}

Suzanne F. Bradley, MD • Ann Arbor, MI

\section{DEPUTY EDITOR}

Carol A. Kauffman, MD • Ann Arbor, MI

\section{SENIOR ASSOCIATE EDITORS}

C. Glen Mayhall, MD • Galveston, TX

Gina Pugliese, RN, MS • Chicago, IL

William Schaffner, MD • Nashville, TN

\section{ASSOCIATE EDITORS}

Carol Chenoweth, MD • Ann Arbor, MI

Ebbing Lautenbach, MD, MPH • Philadelphia, PA

David Weber, MD, MPH • Chapel Hill, NC

\section{STATISTICS CONSULTANTS}

Jon P. Furuno, PhD • Portland, OR

Jessina C. McGregor, PhD • Portland, OR

SECTION EDITOR FOR GUIDELINES, POSITION PAPERS, AND INVITED REVIEWS

Eli Perencevich, MD, MS • Iowa City, IA

MANAGING EDITOR

Meighan Schreiber, MSSA • New York, NY

\section{PAST EDITORS}

Infection Control

Richard P. Wenzel, MD, 1980-1987 (vols. 1-8)

Infection Control \& Hospital Epidemiology

Richard P. Wenzel, MD, 1988-1992

(vols. 9-13)

Michael D. Decker, MD, 1993-2001 (vols. 14-22)

Barry M. Farr, MD, 2002-2004 (vols. 23-25)

William R. Jarvis, MD, 2005-2006 (vols. 26 and 27)

\author{
EDITORIAL ADVISORY BOARD \\ Deverick Anderson, MD, MPH • Durham, NC \\ Anucha Apisarnthanarak, MD • Pratumthani, Thailand \\ Lennox Archibald, MD, FRCP • Alachua, FL \\ Hilary Babcock, MD • St. Louis, MO \\ Shailen Banerjee, PhD • Atlanta, GA \\ Elise M. Beltrami, MD, MPH • Atlanta, GA \\ Jo Anne Bennett, RN, PhD • New York, NY \\ David Birnbaum, PhD, MPH • Sidney, BC \\ Marc Bonten, $\mathrm{MD} \bullet$ Utrecht, Netherlands \\ Christian Brun-Buisson, MD • Creteil, France \\ John P. Burke, MD • Salt Lake City, UT \\ David P. Calfee, MD, MS • New York, NY \\ Yehuda Carmeli, MD, MPH • Tel Aviv, Israel \\ Donald E. Craven, MD • Burlington, MA \\ Christopher Crnich, MD, MS • Madison, WI \\ Erika D’Agata, MD, MPH • Boston, MA \\ Daniel Diekema, MD • Iowa City, IA \\ Erik Dubberke, MD, MSPH • St. Louis, MO \\ Charles E. Edmiston, Jr., PhD • Milwaukee, WI \\ Theodore C. Eickhoff, MD • Denver, CO \\ Mohamad Fakih, MD, MPH • Grosse Pointe Woods, MI \\ Petra Gastmeier, MD • Berlin, Germany \\ Jeffrey Gerber, MD, PhD • Philadelphia, PA \\ Dale N. Gerding, MD • Hines, IL \\ Donald A. Goldmann, MD • Boston, MA \\ Nicholas Graves, PhD • Brisbane, Australia \\ Donna Haiduven, RN, PhD, CIC • Tampa, FL \\ Anthony D. Harris, MD, MPH • Baltimore, MD \\ Elizabeth Henderson, PhD • Calgary, AB \\ David K. Henderson, MD • Bethesda, MD \\ Loreen A. Herwaldt, MD • Iowa City, IA
}

Peter N. R. Heseltine, MD • Brea, CA

John A. Jernigan, MD, MS • Atlanta, GA

James T. Lee, MD, PhD • St. Paul, MN

L. Clifford McDonald, MD • Atlanta, GA

Allison McGeer, MD • Toronto, ON

Leonard A. Mermel, DO, ScM • Providence, RI

Robert R. Muder, MD • Pittsburgh, PA

Linda Mundy, MD • Collegeville, PA

Joseph M. Mylotte, MD, CIC • Buffalo, NY

Jan Evans Patterson, MD • San Antonio, TX

David A. Pegues, MD • Philadelphia, PA

Didier Pittet, MD, MS • Geneva, Switzerland

Isaam Raad, MD • Houston, TX

Manfred L. Rotter, MD, DipBact • Vienna, Austria

William A. Rutala, PhD, MPH • Chapel Hill, NC

Lisa Saiman, MD, MPH • New York, NY

Sanjay Saint, MD, MPH • Ann Arbor, MI

Sorana Segal-Maurer, MD • Flushing, NY

Lynne M. Sehulster, PhD • Atlanta, GA

John A. Sellick, DO • Amherst, NY

Kent Sepkowitz, MD • New York, NY

Andrew E. Simor, MD • Toronto, ON

Philip W. Smith, MD • Omaha, NE

Kurt Stevenson, MD, MPH • Columbus, $\mathrm{OH}$

Nimalie Stone, MD • Atlanta, GA

Thomas Talbot, MD, MPH • Nashville, TN

Paul Tambyah, MBBS • Singapore

William Trick, MD • Chicago, IL

Antoni Trilla, MD, PhD • Barcelona, Spain

Robert A. Weinstein, MD • Chicago, IL

Andreas Widmer, MD, MS • Basel, Switzerland

Marcus Zervos, MD • Detroit, MI
Infection Control \& Hospital Epidemiology (ISSN 0899-823X) is published monthly by Cambridge University Press, 32 Avenue of the Americas, New York, NY 10013, USA.

\section{Editorial Office}

Communications should be addressed to the Editor, Infection Control \& Hospital Epidemiology, 32 Avenue of the Americas, New York, NY 10013 (email: mschreiber@cambridge.org; telephone: 212-337-5954, fax: 212337-5959). Contributors should consult the Instructions for Contributors, which is available at the journal's Web site.

\section{Advertising}

Please direct advertising inquiries to M. J. Mrvica Associates, 2 West Taunton Avenue, Berlin, NJ 08009 (e-mail: mjmrvica@mrvica.com; telephone: 856-768-9360, fax: 856-753-0064). Publication of an advertisement in Infection Control \& Hospital Epidemiology does not imply endorsement of its claims by the Society for Healthcare Epidemiology of America, by the Editor, or by Cambridge University Press.

\section{Permissions}

Articles may be copied or otherwise reused without permission only to the extent permitted by Sections 107 and 108 of the US Copyright Law. Permission to copy articles for personal, internal, classroom, or library use may be obtained from the Copyright Clearance Center (http://www. copyright.com, email: info@copyright.com). For all other uses, such as copying for general distribution, for advertising or promotional purposes, for creating new collective works, or for resale, please contact Cambridge University Press. Full details may be found at: www.cambridge.org/aboutus/rights-permissions.

\section{Subscriptions}

The individual subscription rate for 2015 is \$224. Individuals have the option to order directly from Cambridge University Press. Institutional print + electronic and e-only subscriptions are available from Cambridge University Press and include unlimited online access; rates are tiered according to an institution's type and research output and may be reviewed at the journal's CJO homepage: http://journals.cambridge.org/ICE.

Please direct subscription inquiries and requests for back issues to Customer Services at Cambridge University Press, e-mail: subscriptions_newyork@ cambridge.org (USA, Canada, and Mexico) or journals@cambridge.org (outside of USA, Canada, and Mexico).

Postmaster: Send address changes to Infection Control \& Hospital Epidemiology, Cambridge University Press, 100 Brook Hill Drive, West Nyack, NY 10994-2133, USA. 
About the cover:

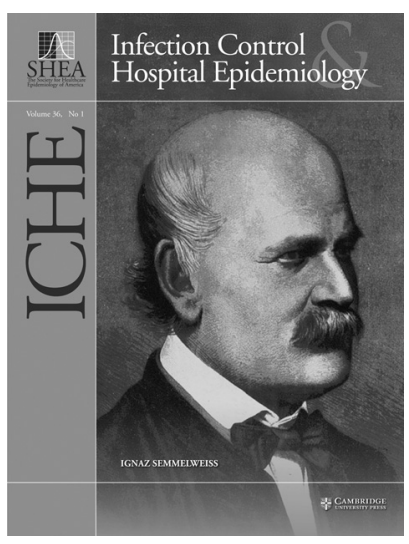

Starting in 2015, the cover format of each volume of Infection Control \& Hospital Epidemiology will highlight one of the many professionals throughout history who not only recognized how disease might be spread, but also how epidemiological principles could be applied to reduce healthcare associated infections.

Ignaz Semmelweiss (1818-1865) was a Hungarian physician who was appointed an assistant in obstetrics at the Allgemeines Krankenhaus in Vienna. He recognized that women delivered by midwife trainees were significantly less likely to die of puerperal fever than those delivered by physicians or medical students. He hypothesized that puerperal fever could be spread to mothers at the time of delivery by the hands of obstetricians that became contaminated while performing autopsies on women who had died in the maternity ward. Controlled trials of hand washing with chloride of lime solution and disinfection of instruments showed that he could reduce infections among the women cared for by physicians by almost 20 -fold. Unfortunately, he did not publish his findings which contributed to the lack of acceptance of antisepsis among senior staff; Semmelweiss' academic appointment was not renewed. He left for Budapest, but his beliefs failed to gain traction among colleagues in Hungary. Semmelweiss' increasingly erratic and angry behavior led to commitment to an asylum; he died there within a few short weeks at the age of 47 years. Contrary to legend, Semmelweiss' autopsy suggests that he did not die of streptococcal gangrene, but rather of trauma related to beatings inflicted by the guards at the asylum and an early Alzheimer-type dementia. 


\section{Not all UV disinfection}

is created equal.
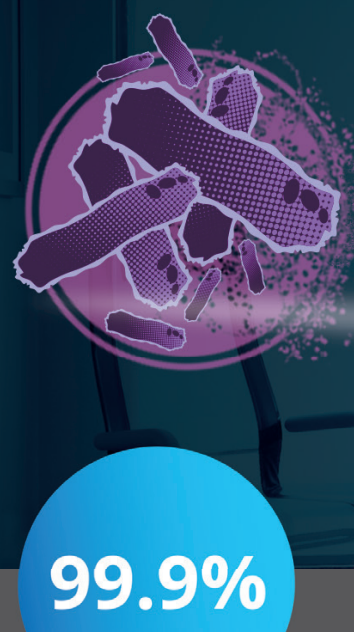

\section{Visit us at Medassets-National Healthcare Business Summit}

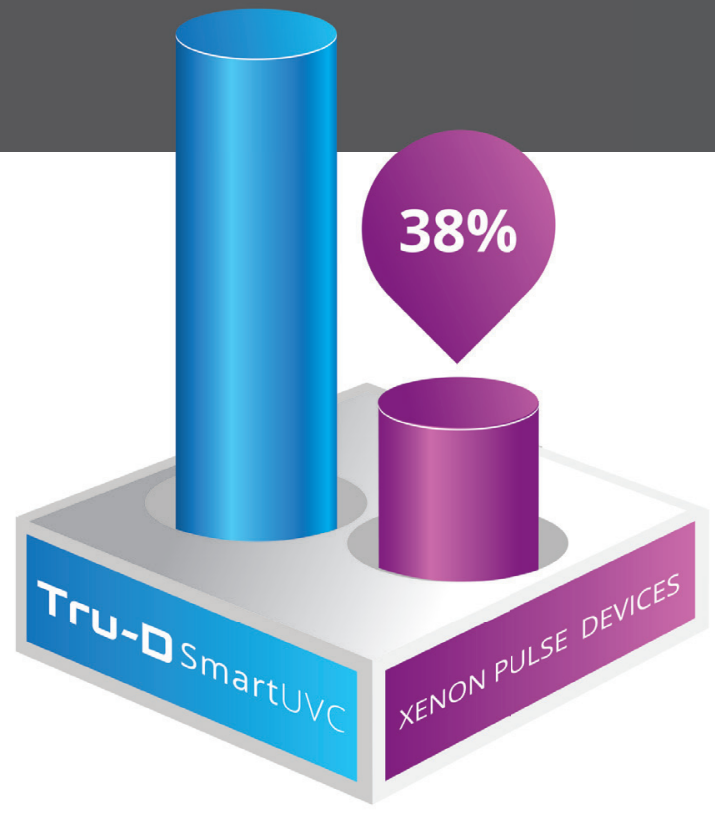

\section{REDUCTION IN VRE}

IN LINE OF SIGHT AREAS

*"First UK trial of Xenex PX-UV room decontamination device," Journal of Infection Prevention, Beal, et al., 2014

\section{Las Vegas, NV • April 7-9}

What makes Tru-D the smart choice is the ability to measure dose. While many disinfection devices claim cycles as short as 5 minutes, what they don't tell you about are the pathogens left behind in shadowed, high-touch surface areas. Tru-D SmartUVC delivers a guaranteed lethal dose in one cycle, with no need to reposition the device.

Eliminate human error in your disinfection process 


\section{Reduce S. aureus Carriage Without Antibiotics}

In a study published in the American Journal of Infection Control, Nozin ${ }^{\circledR}$ Nasal Sanitizer ${ }^{\circledR}$ antiseptic profoundly reduced Staph aureus nasal carriage without antibiotics.*

Now you can:

$\checkmark$ Reduce Nasal Carriage in ICU

$\checkmark$ Eliminate Screen and Isolation

$\checkmark$ Support Antibiotic Stewardship

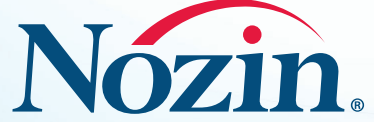

NASAL SANITIZER.

$\overline{\text { NOZASEPTIN }^{\text {TM }} \text { FORMULA ADVANCED ANTISEPTIC }}$

Contact us for a free consultation. Nozin.com 877-669-4648

C2015 Global Life Technologies Corp. All rights reserved. Made in USA.

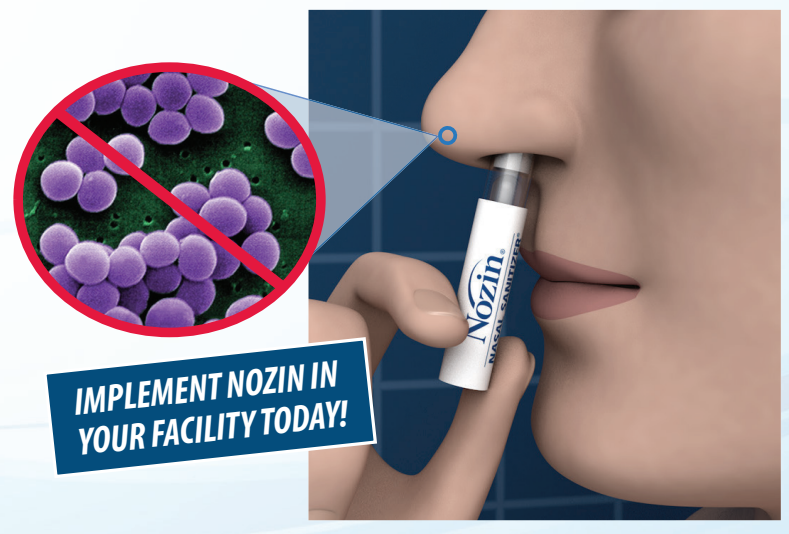

- Clinically proven $\quad$ Low cost

- Easy to apply swab - Pleasant to use

*Steed L, et al. Reduction of nasal Staphylococcus aureus carriage. American Journal of Infection Control. Volume 42, Issue 8, 2014. 